\title{
Nota de Repudio ao Programa Escola Sem Partido
}

O GRUPEFE - Grupo de Pesquisa e Estudo em Filosofia da Educação, em conjunto com o GRUPEC - Grupo de Pesquisa em Estudos da Complexidade, ambos constituídos por docentes e discentes do Programa de Pós-Graduação em Educação da UNINOVE, bem como por profissionais da educação, após acurada análise do Programa Escola Sem Partido, vem a público manifestar total repúdio às propostas de emendas à LDB, consubstanciadas em projetos de lei apresentados por ele, por considerá-las extremamente prejudiciais à educação nacional. Além de ferir acintosamente dispositivos constitucionais, plenamente consolidados, compromete muitos princípios de natureza pedagógica. Entendem os Grupos que, se implementado, o referido Programa esvazia totalmente o sentido da formação humana mediada pela educação institucional, por reduzir o conteúdo do ensino/aprendizagem à transmissão de informações e habilidades e por conceber o ensino como se fosse mera atividade técnica de instrução, desconhecendo a absoluta necessidade de subsidiar os alunos no amadurecimento da própria autonomia intelectual e moral; judicializa as relações pedagógicas, criminalizando atitudes e discursos dos professores, ao induzir abordagem jurídica e até mesmo policial; estimula atitudes de delação e de chantagem entre as pessoas que convivem na comunidade escolar, atitudes que se transformam em meios de acerto de contas e desavenças pessoais; fere o direito da liberdade de expressão, restringindo e inibindo os espaços de manifestação de ideias e posições, não só dos agentes formadores mas também dos alunos; atua como uma mordaça aos professores, ao censurar conteúdos das falas dos mesmos, o que implica também a desvalorização do papel do professor no seio da comunidade; fere o direito e a liberdade dos estudantes de aprenderem mediante ensino qualificado, que seja competente cientificamente, criativo intelectualmente e critico politicamente; cerceia o direito e a necessidade de os alunos acompanharem o desenvolvimento da ciência como instância cultural, em decorrência da imposição priorizante de ideias morais, religiosas e ideológicas supostamente esposadas pelos pais; reforça os preconceitos de homofobia e de misoginia ao censurar e proibir o debate sobre as questões relacionadas à igualdade de gênero e à diversidade sexual; envieza a reflexão acerca do processo histórico, bem como suas consequências, pelos quais passaram diversos grupos étnicos e sociais; impede o fomento do debate sobre o sentido das diversas situações da realidade sociocultural, desconhecendo o necessário pluralismo das ideias e dos valores, consolidando o pensamento único, que se torna então dogmático.

São Paulo, 20 de outubro de 2016. 